\title{
A study of prevalence of thyroid disorders in patients with abnormal uterine bleeding
}

\author{
Ashok Kumar H. S. ${ }^{1 *}$, Saravanan S. ${ }^{2}$
}

\begin{abstract}
${ }^{1}$ Department of Obstetrics and Gynecology, Adichunchangiri Institute of Medical Sciences, Mandya, Karnataka, India ${ }^{2}$ Department of Obstetrics and Gynecology, Government Medical College, Thiruvananthapuram, Kerala, India
\end{abstract}

Received: 27 January 2017

Accepted: 04 February 2017

\section{*Correspondence:}

Dr. Ashok Kumar H. S.,

E-mail: patel.ashok97@gmail.com

Copyright: (C) the author(s), publisher and licensee Medip Academy. This is an open-access article distributed under the terms of the Creative Commons Attribution Non-Commercial License, which permits unrestricted non-commercial use, distribution, and reproduction in any medium, provided the original work is properly cited.

\section{ABSTRACT}

Background: Thyroid gland is the most vital endocrine organ which plays a major role in growth, development, metabolism and function of almost every organ of our body. Both hypothyroidism and hyperthyroidism can result in menstrual irregularities. Abnormal Uterine Bleeding (AUB) is one of the most common, yet complicated clinical presentation. It occurs in 10-20\% of women between 15-50 years of age. Timely detection of thyroid dysfunction in patients presenting with AUB and their proper management can prevent unnecessary surgical interventions. This study was done to analyze the prevalence of thyroid dysfunction in patients with AUB and also to look for different menstrual patterns associated with thyroid dysfunction.

Methods: This is a prospective study conducted at Department of Obstetrics and Gynecology, Government Medical College, Manjeri, Kerala, India. Total 200 patients were recruited into present study after satisfying all inclusion and exclusion criteria. Complete history was taken followed by a thorough examination. Baseline investigations and T3, T4, TSH was performed in all patients. Results were analyzed.

Results: As per present study, majority of the patients with AUB were from the age group of 35-49 years (43\%). In patients with AUB with thyroid dysfunction, prevalence of subclinical hypothyroidism was most common followed by hypothyroidism. According to our study thyroid dysfunction was most commonly seen in the age group of 35-49 years, and the most common presentation being menorrhagia.

Conclusions: Timely diagnosis and proper management of thyroid dysfunction in women with AUB can avoid variety of non-specific and ineffective diagnostic and therapeutic procedures.

Keywords: AUB, Hyperthyroidism, Hypothyroidism, Menstrual disorders, Subclinical hypothyroidism, Thyroid dysfunction

\section{INTRODUCTION}

Thyroid gland is one of the most important vital endocrine organ which plays a major role in growth, development, metabolism and function of almost every organ of our body. ${ }^{1}$ It weighs just around 10 to 30 grams in people with satisfactory iodine consumption. ${ }^{2}$

In women, thyroid disorders can cause a broad spectrum of reproductive illness ranging from abnormal sexual development to infertility, menstrual irregularities and premature menopause. ${ }^{3}$ Thyroid disorders are around 10 times more common in females and this high prevalence is possibly due to autoimmune nature of thyroid disorders. $^{4}$

Thyroid disorders are the most common endocrine disorders in India. ${ }^{5}$ Incidence of thyroid disorders increases with age ant its prevalence is around $26 \%$ in women. ${ }^{6}$ Both hypothyroidism and hyperthyroidism can result in menstrual irregularities. Association of amenorrhoea with hyperthyroidism has been described as 
early as 1840 by Von Bosedow. ${ }^{7}$ It usually results in oligomenorrhoea and anovulation. The mechanism of anovulation in hyperthyroidism is incompletely understood, whether it is primary effect of thyroid on uterus and ovary or mediated by pituitary dysfunction. Hypothyroidism, however even in its subclinical form usually tends to cause menorrhagia. It is usually because of failure of LH production, anovulation, building up of endometrium and resultant menorrhagia.

Abnormal uterine bleeding (AUB) is one of the most common, yet complicated clinical presentation. ${ }^{8}$ It occurs in 10-20\% of women between 15-50 years of age. ${ }^{9}$ AUB is a very broad term which can occur secondary to various aetiologies and it can be defined as any deviation from the normal menstrual cycle and it includes changes in frequency or regularity of menses or duration or amount of blood loss. Various terms used to describe AUB include menorrhagia, polymenorrhagia, polymenorrhoea, oligomenorrhoea, hypmenorrhea, metrorrhagia, amenorrhoea. ${ }^{10}$

Depending upon its aetiology and to ease its confusing management, AUB has been categorised into 9 main categories by International Federation of Obstetrics and Gynecology. The categories are arranged according to the acronym PALM-COEIN: polyp, adenomysis, leiomyoma, malignancy and hyperplasia, coagulopathy, ovulatory disorders, endometrial causes, iatrogenic, not classified. ${ }^{11}$ Among all the aetiologies listed above, ovulatory disorder is one of the most common cause which usually occur secondary to thyroid dysfunction. Many studies like Danese MD et al and Douglas L Wilansky et al have stated that any menstrual irregularity in non-pregnant women justifies screening for thyroid disorders. ${ }^{12,13}$ Timely detection of thyroid dysfunction in patients presenting with AUB and their proper management can prevent unnecessary surgical interventions and helps to reduce financial burden and improves the quality of life. Hence this study is to evaluate the thyroid dysfunction in patients having AUB from puberty till menopause.

\section{Aims and objectives}

- To assess and analyse the prevalence of thyroid dysfunction in patient presenting with AUB from puberty till menopause.

- To determine the different patterns of menstrual abnormalities associated with various thyroid disorder

\section{METHODS}

This is a prospective study conducted at Department of Obstetrics and Gynecology, Governmentt Medical College, Manjeri, Kerala, India. It was done for a period of one year from July 2014 to June 2015. Total 200 patients were recruited into our study after satisfying all inclusion and exclusion criteria. Ethical committee clearance was taken before starting the study.

\section{Inclusion criteria}

All women from puberty till menopause presenting to outpatient department with AUB

\section{Exclusion criteria}

- Pregnant women or women with history of childbirth in last 1 year or women with history of abortion in last 3 months

- Women with IUCD/ on Hormone therapy

- Women with known history of liver disorders/coagulopathy

- Known case of autoimmune disorders

- Known case of malignancy of genital organs

- Refusal to give consent

Complete history was taken from all recruited patients with regards to age, parity, menstrual history, onset and duration of complaints, amount of blood flow and any other specific complaints. Following which a thorough examination was carried out which includes general physical examination, systemic examination, gynecoloical and pelvic examination in married women. All the findings were noted down in a predesigned pro forma. Basic routine investigations like $\mathrm{Hb}, \mathrm{PCV}$, RBS, urine routine, BT, CT, ESR, Chest $\mathrm{X}$ ray, pap smear and ultrasound of abdomen and pelvis were performed. Then T3, T4, TSH was done in all patients. Patients with $\mathrm{TSH}<0.5$ were considered as hyperthyroid and $\mathrm{TSH}>5$ were considered as hypothyroid. Based on these values, patients were categorised into 4 groups.

- Euthyroidism

- Hypothyroidism

- Subclinical hypothyroidism

- Hyperthyroidism.

\section{RESULTS}

As per present study, majority of the patients (Table 1) with AUB were from the age group of 35-49 years $(43 \%)$. Parity wise AUB was more common in Nulliparous women which is closely followed by 2 nd parity women (Table 2).

Table 1: Age wise distribution.

\begin{tabular}{|lll|}
\hline Age & No. of patients & Percentage \\
\hline$\leq 20$ years & 34 & 17 \\
\hline 21 -34 years & 68 & 34 \\
\hline 35-49 years & 86 & 43 \\
\hline$\geq 50$ years & 12 & 6 \\
\hline
\end{tabular}

In patients with $\mathrm{AUB}$, as far as thyroid dysfunction was considered, prevalence of subclinical hypothyroidism was most common followed by hypothyroidism (Table 3). According to our study thyroid dysfunction was most commonly seen in the age group of 35-49 years (Table 
4), and the most common presentation being menorrhagia (Table 5 and 6).

Table 2: Parity wise distribution.

\begin{tabular}{|lll|}
\hline Parity & No of patients & Percentage (\%) \\
\hline Nullipara & 86 & 43 \\
\hline P1 & 16 & 8 \\
\hline P2 & 80 & 40 \\
\hline P3 & 8 & 4 \\
\hline P $\geq 4$ & 10 & 5 \\
\hline
\end{tabular}

Table 3: Distribution of patients according to thyroid function status.

\begin{tabular}{|lll|}
\hline Thyroid function status & $\begin{array}{l}\text { No. of } \\
\text { patients }\end{array}$ & Percentage \\
\hline Euthyroid & 162 & 81 \\
\hline Hypothyroid & 12 & 6 \\
\hline Subclinical hypothyroid & 21 & 10.5 \\
\hline Hyperthyroid & 5 & 2.5 \\
\hline
\end{tabular}

Table 4: Age wise distribution of patients with thyroid dysfunction.

\begin{tabular}{|lllll|}
\hline Age & Hypothyroid $(n=12)$ & Subclinical Hypothyroid $(n=21)$ & Hyperthyroid $(\mathbf{n}=\mathbf{5})$ & Total $(\mathbf{n = 3 8 )}$ \\
\hline$\leq 20$ years & 1 & 1 & 0 & $2(5.26 \%)$ \\
\hline 21-34 years & 2 & 6 & 1 & $9(23.68 \%)$ \\
\hline $35-49$ years & 7 & 11 & 2 & $20(52.63 \%)$ \\
\hline$\geq 50$ years & 2 & 3 & 2 & $7(18.42 \%)$ \\
\hline
\end{tabular}

Table 5: Pattern of bleeding in thyroid dysfunction.

\begin{tabular}{|c|c|c|c|c|}
\hline Pattern of bleeding & Hypothyroid (n=12) & $\begin{array}{l}\text { Subclinical hypothyroid } \\
(\mathrm{n}=21)\end{array}$ & Hyperthyroid $(\mathrm{n}=5)$ & Total $(\mathrm{n}=38)$ \\
\hline Menorrhagia & 8 & 12 & 1 & $21(55.26 \%)$ \\
\hline Polymenorrhoea & 1 & 2 & 0 & $3(7.89 \%)$ \\
\hline Polymenorrhagia & 1 & 2 & 0 & $3(7.89 \%)$ \\
\hline Amenorrhoea & 1 & 2 & 1 & $4(10.52 \%)$ \\
\hline Metrorrhagia & 1 & 1 & 0 & $2(5.26 \%)$ \\
\hline Oligomenorrhoea & 0 & 1 & 3 & $4(10.52 \%)$ \\
\hline Hypmenorrhea & 0 & 1 & 0 & $1(2.6 \%)$ \\
\hline
\end{tabular}

Table 6: Bleeding patterns in various age groups.

\begin{tabular}{|c|c|c|c|c|c|c|c|}
\hline Age (n) & Menorrhagia & $\begin{array}{l}\text { Poly- } \\
\text { menorrhoea }\end{array}$ & $\begin{array}{l}\text { Poly- } \\
\text { menorrhagia }\end{array}$ & Amenorrhoea & Metrorrhagia & $\begin{array}{l}\text { Oligo- } \\
\text { menorrhoea }\end{array}$ & $\begin{array}{l}\text { Hypmeno } \\
\text { rrhea }\end{array}$ \\
\hline$\leq 20$ years $(34)$ & 15 & 2 & 6 & 8 & 1 & 2 & 0 \\
\hline $21-34$ years $(68)$ & 32 & 8 & 10 & 6 & 2 & 8 & 2 \\
\hline $35-49$ years $(86)$ & 24 & 12 & 14 & 14 & 4 & 13 & 4 \\
\hline$\geq 50$ years $(12)$ & 5 & 2 & 3 & 0 & 1 & 0 & 0 \\
\hline Total & $76(38 \%)$ & $24(12 \%)$ & $33(16.5 \%)$ & $27(13.5 \%)$ & $8(4 \%)$ & $26(13 \%)$ & $6(3 \%)$ \\
\hline
\end{tabular}

\section{DISCUSSION}

In present study, majority of the patients were in the age group of 35-49 year (43\%) followed by 21-34 years (34\%). This correlates with other studies like Narula et al and Sangeets Pahwa et al, where $32.8 \%$ and $42 \%$ patients were there in the age group of $31-45$ years respectively. ${ }^{14,15}$

In the present study, majority of patients were nulliparous (43\%), followed by 2 nd parity women (40\%). This contradicts the report by Pilli et al, where in $87 \%$ of the patients were multiparous women and nulliparous women were only $7 \% .^{16}$
Among 38 patients with thyroid dysfunction, only 5 patients $(13.15 \%)$ had hyperthyroidism. Remaining $86.7 \%$ of patients had hypothyroidism (both overt and subclinical). This is comparable with other studies like Padmaleela et al. ${ }^{17}$

In our study majority of patients with thyroid dysfunction were from the age group of 35-49 years (52.63\%). This is comparable with Padmaleela et al $(53 \%) .{ }^{17}$

Most common menstrual irregularity found in our study was menorrhagia, which was seen in $55.26 \%$ of patients. 
Table 7: Menorrhagia in thyroid dysfunction; various studies.

\begin{tabular}{|ll|}
\hline Studies & Menorrhagia \\
\hline Wiansky and Bernard & $100 \%$ \\
\hline Doifode et al & $63.3 \%$ \\
\hline Singh et al & $44.4 \%$ \\
\hline Present study & $55.2 \%$ \\
\hline
\end{tabular}

In this study of the total cases of hyperthyroidism, $60 \%$ of patients presented with oligamnios which is similar to Singh et al $(63.6 \%) .{ }^{18-20}$

\section{CONCLUSION}

The menstrual irregularities are significantly more common in patients with thyroid dysfunction and in some cases it may even precede thyroid dysfunction. Estimation of T3, T4, TSH should be a part of investigations done in patients presenting with AUB, since thyroid dysfunction forms an important treatable cause of AUB. Timely diagnosis and proper management of thyroid dysfunction in women with AUB can avoid variety of non-specific and ineffective diagnostic and therapeutic procedures.

Funding: No funding sources Conflict of interest: None declared

Ethical approval: The study was approved by the Institutional Ethics Committee

\section{REFERENCES}

1. Olive D, Palter S. Reproductive physiology. In: Berek JS, eds. Berek and Novak's Gynaecology. 14th ed. Philadelphia: Lippincott Williams and Wilkins Company; 2002:161-86.

2. Ron E, and Brenner A, Non-Malignant Thyroid Diseases Following a Wide Range of Radiation Exposures. NIH Public Access. 2010;174(6):877-8.

3. Thomas R, Reid RL. Thyroid diseases and reproductive dysfunction. Obstet Gynaecol. 1987;70:789-98.

4. Mazzaferri EL. Evaluation and management of common thyroid disorders in women. Am J Obstet Gynaecol. 1997;176(3):144-9.

5. Kochupillai N. Clinical endocrinology in India. Curr Sci. 2000;79:1061-7.

6. Hollowell JG, Staehling NW, Flanders WD. Serum TSH, T4 and thyroid antibodies in the United States population (1988 to 1994): National health and nutrition examination survey (NHANES III). J Clin Endocrinol Metab. 2002;87(2):489-99.

7. Steiner RA, Fink D. Abnormal menstrual bleeding. Schweiz Rundsch Med Prax. 2002;91:1967-74.

8. ACOG practice bulletin: management of anovulatory bleeding. Int J Gynaecol Obstet. 2001;72:263-71.

9. Nesse R. Abnormal vaginal bleeding in perimenopausal women. Am Family Physician. 1989;40:185.

10. Speroff L. Glass RH, Kass NG. In:Clinical gynaecologic Endocrinology and infertility. 6th ed. Baltimore: Lippincott Williams and Wilkins. 1999; 201-238,575-9.

11. M.G. Munro. FIGO classification system (PALMCOEIN) for causes of abnormal uterine bleeding innongravid women of reproductive age. Int $\mathbf{J}$ Gynecol Obstet. 113(2011):3-13.

12. Doifode CD, Fernandes K. Study of thyroid dysfunction in patients with dysfunctional uterine bleeding. J obstet and gynecol of India. 2001;51(2):93-5.

13. Wilansky DL, Grisesman B. Early hypothyroidism in patients with menorrhagia. Am J Obstet Gynaecol. 1990;163(2):697.

14. Narula ER; Menstrual Irregularities. J Obstet Gynecol India. 1967;17:164.

15. Pahwa S, Gupta S, Kumar J. Thyroid dysfunction in dysfunctional uterine bleeding. J Adv Res Biol Sci. 2013;5(1):78-83.

16. Pilli GS, Sethi B, Dhaded AV, Mathur PR. Dysfunctional uterine bleeding. J Obstet Gynecol India. 2001;52(3):87-9.

17. Padmaleela K, Thomas V, Lavanya KM, Kiranmai D. Thyroid disorders in dysfunctional uterine bleeding among reproductive age group women- a cross sectional study in a tertiary hospital in Andhra Pradesh, India. Int J Med Pharm Sci. 2013;04(01):41-6.

18. Braverman L, Cooper D. The thyroid. In: Braverman L, Cooper D. eds. Ingbar and Werner's Fundamental and Clinical Text. 10th ed. Philadelphia: Lippincott Williams and Wilkins Company; 2012:792.

19. Doifode CD, Fernandes K. Study of thyroid dysfunction in patients with dysfunctional uterine bleeding. J Obstet Gynecol India. 2001;51:93-5.

20. Singh L, Agarwal CG, Choudhary SR, Mehra P, Khare R. Thyroid profile in infertile woman. J Obstet Gynecol India. 1990;40:248.

Cite this article as: Kumar AHS, Saravanan S. A study of prevalence of thyroid disorders in patients with abnormal uterine bleeding (AUB). Int J Reprod Contracept Obstet Gynecol 2017;6:1036-9. 